\title{
Chronic phase of Chagas disease: why should it be treated? A comprehensive review
}

\author{
José Rodrigues Coura/ ${ }^{+}$, José Borges-Pereira \\ Laboratório de Doenças Parasitárias, Instituto Oswaldo Cruz-Fiocruz, Av. Brasil 4365, 21040-360 Rio de Janeiro, RJ, Brasil
}

The pathogenesis and evolutive pattern of Chagas disease suggests that the chronic phase should be more widely treated in order to (i) eliminate Trypanosoma cruzi and prevent new inflammatory foci and the extension of tissue lesions, (ii) promote tissue regeneration to prevent fibrosis, (iii) reverse existing fibrosis, (iv) prevent cardiomyopathy, megaoesophagus and megacolon and (v) reduce or eliminate cardiac block and arrhythmia. All cases of the indeterminate chronic form of Chagas disease without contraindications due to other concomitant diseases or pregnancy should be treated and not only cases involving children or recently infected cases. Patients with chronic Chagas cardiomyopathy grade II of the New York Heart Association classification should be treated with specific chemotherapy and grade III can be treated according to medical-patient decisions. We are proposing the following new strategies for chemotherapeutic treatment of the chronic phase of Chagas disease: (i) repeated short-term treatments for 30 consecutive days and interval of 30-60 days for six months to one year and (ii) combinations of drugs with different mechanisms of action, such as benznidazole + nifurtimox, benznidazole or nifurtimox + allopurinol or triazole antifungal agents, inhibition of sterol synthesis.

Key words: Chagas disease - chronic phase - chemotherapy - new strategies - repeated treatment - combination of drugs

The chronic phase of Chagas disease is the longest period during its evolution after the acute or initial phase of the disease. The two to three months of the acute phase are followed by a long chronic period that is initially asymptomatic without electrocardiographic and/ or radiological abnormalities in the heart, oesophagus or colon, which has been described by Carlos Chagas (1916) as the "indeterminate chronic form". This concept was validated by a group of experts during the Applied Research Meeting on Chagas disease, held in Araxá, Minas Gerais (MG), Brazil (Anonymous 1985), even though it was known that every year, $2-5 \%$ of the cases of this clinical form would evolve into cardiac or digestive symptomatic forms (Macedo 1980, Dias 1989). Despite the possibility of this evolution, Laranja et al. (1956) defined the indeterminate form as "potential cardiac". Incidentally, the evolutive potential of the indeterminate form of Chagas disease had already been ascertained to be a "transitional form" by Villela (1923) in a clinical description of the disease.

Studies on the evolution of Chagas disease conducted by our group (Coura 1975, Coura et al. 1983, 1984, 1985, 1999, Borges-Pereira et al. 1985, Coura \& Borges-Pereira 2010) in different areas of Brazil have demonstrated that, in addition to great regional variation in morbidity due to Chagas disease, approximately $30 \%$ of cases of the indeterminate form may evolve into the mild cardiac form [grade II of the New York Heart Association classification (NYHA1973)], but with an excellent prognosis

Financial support: CNPq (471716/2009-0/473430/2009-6)

+ Corresponding author: coura@ioc.fiocruz.br

Received 3 May 2011

Accepted 23 August 2011 similar to the prognosis for non-Chagas disease controls of the same age and sex. Evolution from the indeterminate form to cardiopathy of NYHA grades III and IV is rarer and occurs slowly, as in cases that evolve into megaoesophagus and megacolon. Approximately 40\% of cases of the indeterminate form do not evolve into cardiopathy and the "mega" forms, but there is no clinical marker indicating whether evolution will occur. The occurrence rate of this evolution is extremely variable, ranging from $10-60 \%$ from one region to another. Acute cases of greater severity resulting from a higher parasitic burden tend to evolve into clinical forms that are also more severe (Castro 1978, Dias 1982, Borges-Pereira 1997). In an observational study that we conducted in Rio de Janeiro over a 30-year period on 510 individuals from several Brazilian states who were serologically positive for Chagas infection (Coura et al. 1983), 39\% remained in the indeterminate form, $52.1 \%$ presented with cardiopathy and $14.3 \%$ presented with megaoesophagus and/or megacolon. Among the "mega" cases, 5.4\% presented associations with cardiopathy and most of these patients were between the ages of 20-49 years, i.e., at the most productive stage of life. What would have happened if all the chronic patients had been treated before they developed cardiopathy and megaoesophagus? The vast majority would certainly not have evolved into these clinical forms. In our study, cardiopathy was present in $65.7 \%$ of the patients originating from Bahia, in $55.9 \%$ of the patients from $\mathrm{MG}$, in $50.9 \%$ of the patients from Pernambuco and in only $23.3 \%$ of the patients from Paraíba (PB), whereas the cases of "megas" affected $20.1 \%, 14.7 \%, 15 \%$ and $0 \%$ of the patients originating from these states, respectively. We subsequently also observed these differences in field studies conducted in MG and PB. In the latter state, disease morbidity was strikingly lower (Macedo et al. 1982, Coura et al. 1983, 
1984). Finally, based on the positive findings of Trypanosoma cruzi from the xenodiagnosis observed by our group and by others and its correlation with morbidity in the chronic phase of Chagas disease, we suggest that treatment should be provided not only for acute and recently chronic cases, as previously indicated (Coura \& De Castro 2002), but for all cases, provided that there is no formal contraindication due to other concomitant diseases or pregnancy.

The aims of this review were to analyse the possibility of expanding the use of chemotherapy for Chagas disease based on its pathogenesis in order to prevent the infection from evolving into forms of greater severity and to indicate which patients should be treated and how treatment should be carried out. Recommended treatment would use new regimens consisting of associations between existing drugs and/or the prolongation of treatment with short-term repetition aimed at exhausting the potential for parasite development and, consequently, blocking the evolution of the disease.

Current recommendations for chemotherapeutic treatment - The current recommendations for chemotherapeutic treatment of Chagas disease are based on decisions made by specialists who were brought together by the Brazilian Ministry of Health in 1997, as well as the Pan-American Health Organization and the World Health Organization in 1998 (Luquetti 1997, Prata 2001, Coura \& De Castro 2002); thus, these recommendations were made 13-14 years ago. These recommendations suggest that immediate treatment should be provided for all acute cases caused by vector transmission, oral transmission, congenital infection, laboratory accidents, organ transplantation or any other route and for cases in the "recent indeterminate chronic phase". Regardless of whether symptoms are present, cases are considered to be in the acute or initial phase if $T$. cruzi is present in peripheral blood (Figure), as determined by direct microscopic examination of fresh blood smears or by concentration methods (e.g., microhaematocrit, Strout or QBC). IgM has also been considered to be an acute phase indicator, but this is currently regarded with much doubt in the absence of other confirmations (Consenso SVS/MS 2005). Treatment of the indeterminate phase has been established in children up to 12 years of age based on the positive results obtained from specific treatment by Andrade et al. (1996) in Brazil and Sosa-Estani et al. (1998) in Argentina. Cases of the later chronic form in children over the age of 12 could be treated at the discretion of the physician and patient because poor results have been obtained so far with regard to cure and control, but without considering the evolution of the disease.

Basis for new chemotherapy recommendations for chronic Chagas disease - Since the pioneering studies of Gaspar Vianna (1911) on the pathology of Chagas disease, it has been demonstrated that the main mechanism for tissue lesions is the inflammatory reaction induced by T. cruzi after the "pseudocysts" have ruptured and have consequently undergone repair with fibrosis formation. Although there may be secondary autoimmunity mechanisms, there is now a consensus that these mechanisms always result from the presence of $T$. cruzi and its anti- gens. The experimental studies by Andrade et al. (1991) clearly demonstrated that fibrosis was reversible in mice with chronic $T$. cruzi infection when treated with specific chemotherapy. Specific chemotherapy suppresses parasitaemia, eliminates trymastigotes from blood and amastigotes from tissue and may reverse fibrosis. Similarly, the destruction of the neuron plexi of the oesophagus by the inflammatory reaction induced by $T$. cruzi leads to dysperistalsis of the oesophagus grade I, II, III and IV, resulting in odynophagia and moderate or severe dysphagia until deglutition becomes impossible. An identical mechanism may occur in the colon, small intestine and other hollow viscera (Rezende-Filho et al. 2005).

Why treat the chronic phase of Chagas disease? There are no convincing studies in the medical literature with sufficiently large samples and adequate control groups (with a length of observation of at least 15-20 years) that may indicate whether specific treatment is effective in preventing evolution of the chronic phase of Chagas disease (except for the BENEFIT project, which is currently in progress). Nonetheless, knowledge of the pathogenesis and evolution of Chagas disease suggests that cases in the chronic phase should be more widely treated, with the following aims: (i) to progressively reduce the quantity of $T$. cruzi in the organism until it is totally eliminated, thereby avoiding the formation of new inflammatory foci and the extension of tissue lesions, (ii) to promote tissue regeneration through parasite inactivation in the existing tissue foci, thus avoiding the formation of consolidated fibrosis, (iii) to reverse existing fibrosis, as demonstrated experimentally, and to reverse the functional alterations of the autonomic system and the structural alterations of the myocardial conduction system, (iv) to prevent myocardial hypertrophy and myocardial, oesophageal and colonic dilatation, thereby preventing dilated cardiopathy and the "megas" and, consequently, their functional alterations and (v) to reduce or eliminate cardiac block and arrhythmia, which almost always leads to sudden death among patients.

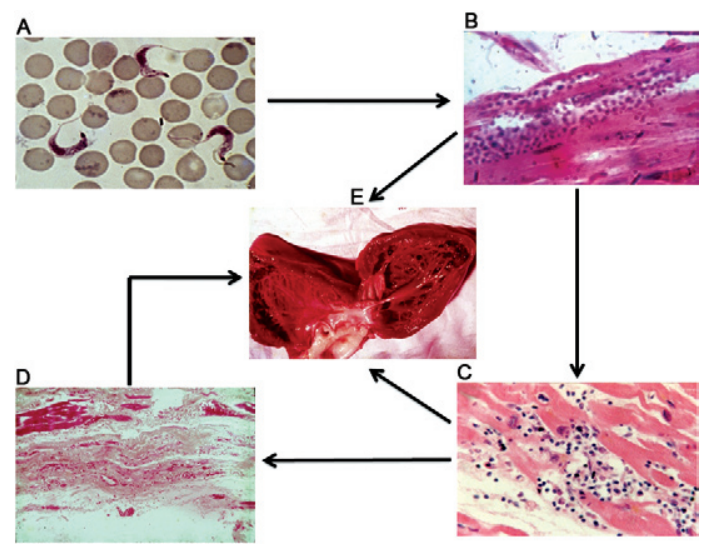

Pathogenesis of chronic Chagas heart disease. A: blood trypomatigotes; B: tissue "pseudocysts" of amastigotes; C: inflammatory reaction with lesion of cardiac fibres; D: healing with tissue fibrosis; E: heart hypertrophy and dilatation. 
Who should be treated during the chronic phase of Chagas disease? - All cases of the indeterminate chronic form of Chagas disease without contraindications due to other concomitant diseases or pregnancy should be treated and not just cases involving children. By definition, the indeterminate form of Chagas disease is presented by individuals whose serological and/ or parasitological tests are positive for Chagas infection, but without clinical manifestations, with normal results from electrocardiograms and radiography on the heart, oesophagus and colon (Macedo 1980, Anonymous 1985, Dias 1989, Ribeiro \& Rocha 1998, 2000). This concept was put forward by Chagas (1916) and Villela (1923) and was validated at the Applied Research Meeting on Chagas disease held in Araxá (Anonymous 1985). This definition does not mean that the indeterminate chronic form does not have small inflammatory foci in the myocardium (Mady et al. 1984, Carrasco et al. 1987) or abnormalities, as indicated by ergometry, dynamic electrocardiography, echocardiography and myocardial scintigraphy (Ribeiro \& Rocha 2000, Rocha et al. 2005) and unexpected sudden death (Prata et al. 1986, RassiJunior et al. 2005). However, these findings do not invalidate the good prognosis of this clinical form (Coura 2007, Coura \& Borges-Pereira 2010).

In patients with NYHA grade II cardiopathy and moderate to no symptoms, the following abnormalities are almost always stable with a good prognosis: slight electrocardiographic abnormalities, isolated monomorphic ventricular extrasystole, first-degree atrioventricular (AV) block, incomplete right branch block, isolated third-degree right branch block or primary repolarisation abnormalities. These patients should also be treated with specific chemotherapy because of the high probability of regression of the first degree AV block, ventricular repolarisation disorders and isolated monomorphic ventricular extrasystoles and/or stabilisation of these abnormalities.

Patients presenting with NYHA grade III should also be considered for treatment. These patients present with symptoms of cardiac hypertrophy, polymorphic extrasystoles, second and third-degree AV block, complete right branch block, partial left anterior block (fascicular block) and complex arrhythmia. They should undergo symptomatic treatment for arrhythmia and heart failure. These cases need to be assessed by the attending physician with regard to the risks and benefits of chemotherapy.

For cases with grades I and II megaoesophagus according to the classification by Rezende et al. (1960), the lack of studies regarding the regression of functional abnormalities should not prevent these patients from undergoing specific chemotherapy. However, patients with grades III and IV of this classification are unlikely to achieve regression of dilatations that have become established. Megacolon cases can be considered using the same reasoning.

How should the chronic form of Chagas disease be treated? - Several attempts to find specific treatment for Chagas disease were made following the experimental studies of Mayer and Rocha Lima (1912, 1914) using arsenicals (atoxyl), rosaniline stains (fuchsine), emetic tartar (trivalent antimonials) and mercury chloride, all without favourable results. In the Manual on Tropical and Infectious Diseases, vo. 1, written by Carlos Chagas and Evandro Chagas (1935), only a single paragraph on the treatment of Chagas disease appears; the brief section states the following: "So far, there is no specific treatment for American trypanosomiasis. Experiments on medications with trypanosomicidal action have been conducted by several researchers without any success".

In our review on this subject (Coura \& Silva 1961), the following groups of substances have been used clinically and experimentally: quinolone derivatives, antimalarials, arsenobenzols and other arsenical compounds, phenanthridines, gold salts, bismuth, copper, zinc, sodium iodide, gentian violet, aminopterin, paraminosalicylic acid, hydrazide, sulfonamides, corticotropic hormones and cortisone, stylomycin derivatives, amphotericin B and more than 30 antibiotics. However, the results were either not favourable or caused controversy, according to Cançado (1968). Some nitrofurans have been shown in experiments to be promising, according to Packchanian $(1952,1957)$.

The curative action of nitrofurazone was definitively proven in 1961. Brener (1961) used this drug at a dose of $100 \mathrm{mg} / \mathrm{kg} /$ day for prolonged periods (53 days) in mice infected with T. cruzi and demonstrated that $95.4 \%$ of the animals treated achieved a parasitological cure (62/65).

Ferreira (1961, 1962) and Ferreira et al. (1963) observed "good results" with few side effects among children in the acute phase of the disease who were treated with nitrofurazone. Coura et al. $(1961,1962)$ treated 14 cases of chronic Chagas disease in adults using this drug at progressive doses going from $10-30 \mathrm{mg} / \mathrm{kg} / \mathrm{day}$ for prolonged periods, but significant side effects were observed, particularly polyneuropathy. For 10 patients treated during a 60-day period, the dose had to be reduced to $10 \mathrm{mg} / \mathrm{kg} /$ day. Three of the patients achieved a cure, one of which had a recently chronic form of the disease acquired in Goiás 18 months earlier.

More recently, Coura \& De Castro (2002) published the extensive "Critical Review on Chagas Disease Chemotherapy" in which they analysed the experimental and clinical studies developed since 1970, including the rules and recommendations for clinical treatment, the perspectives for new drugs undergoing clinical tests and promising new targets. One new strategy for clinically treating Chagas disease was put forward by Coura (2009), which suggested that a combination of existing drugs could be used, as is successfully done in cases of tuberculosis, leprosy, immune deficiency syndrome and many other infectious diseases, but such a combination has not yet been adopted for Chagas disease.

Currently, only two drugs are considered to be effective for treating Chagas disease in the acute and chronic phases: nifurtimox and benznidazole (Coura 1996, Coura et al. 1978, 1997). The mechanism of action of nifurtimox involves the production of nitro-anion radicals that, in the presence of oxygen, leave T. cruzi incapable of detoxifying free radicals (Do Campo \& Moreno 1986).

Nifurtimox has been used at a dose of $8-10 \mathrm{mg} / \mathrm{kg} / \mathrm{day}$, divided into two-three doses per day, for a 60-day period by several authors cited by Coura \& De Castro (2002) and Coura (2009). The mechanism of action of benznidazole relates to the nitro-reduction of components of the parasite, the binding of metabolites of the nuclear DNA and kDNA of T. cruzi and the lipids and proteins of the parasite (Polack \& Richle 1978, Diaz de Taranzo et al. 1988). 
Benznidazole has been used at a dose of $5-7.5 \mathrm{mg} / \mathrm{kg} /$ day in the form of two-three doses per day over a 60-day period by several authors (Coura \& De Castro 2002, Coura 2009). In a comparative controlled study with a placebo group, Coura et al. (1997) demonstrated that benznidazole was more effective than nifurtimox for suppressing parasitaemia during the chronic phase of Chagas disease.

Several other drugs have been found to be effective in vitro against $T$. cruzi, but their action in vivo, including in treating Chagas disease in humans, has caused controversy. Among these drugs, the following can be highlighted: allopurinol, which is a hypoxanthine analogue that inhibits xanthine-oxidase and is used as a hyperuricaemic drug for treating gout, and ergosterol-inhibiting antifungal agents, such as ketoconazole (a derivative of imidazole), fluconazole and itraconazole (triazole derivatives) and, most recently, posaconazole (another azole derivative).

In the classical regimens for treating the chronic phase of Chagas disease, benznidazole is used at a dose of 5-7.5 $\mathrm{mg} / \mathrm{kg} / \mathrm{day}$ and nifurtimox is used at a dose of $8-10 \mathrm{mg} /$ $\mathrm{kg} / \mathrm{day}$, two or three times a day, every $12 \mathrm{~h}$ or every eight hours. However, a multicentre study on 309 patients (54 in the acute phase and 255 in the chronic phase) in which 10 centres in Brazil collaborated with the Roche Laboratory (Coura et al. 1978), used benznidazole in different regimens and found that there were no statistically significant differences in the suppression of parasitaemia (as assessed using xenodiagnosis) between the doses of 5,7 or $8 \mathrm{mg} / \mathrm{kg} / \mathrm{day}$. Nor was there any statistically significant difference in parasite suppression from benznidazole use for 30 or 60 days. Side effects occurred more frequently and were more severe with the dose of $8 \mathrm{mg} / \mathrm{kg} /$ day than with doses of 5 and $7 \mathrm{mg} / \mathrm{kg} /$ day and they were less frequent when the drug was used for only 30 days. In another controlled study performed in the field using benznidazole, nifurtimox and placebo (Coura et al. 1997), it was found that the suppressive effect was greater with benznidazole, whereas the side effects were similar.

New strategies for chemotherapeutic treatment for the chronic phase of Chagas disease - Based on the pathogenesis of Chagas disease and its evolution, which is directly related to the parasite burden and the behaviour of different strains and clones of $T$. cruzi, we are suggesting that new chemotherapeutic treatment strategies should be used. The aims of these strategies are to exhaust tissue parasitism and, consequently, eliminate lesions and the evolution of the chronic phase.

Based on the mechanisms of action of existing medications and their actions against $T$. cruzi, we suggest that, in addition to the drug associations proposed previously (Coura 2009), shorter and repeated treatment regimens should be used to prolong treatment and to avoid or at least reduce their adverse effects. The following propositions should be adapted through experimental clinical studies with the aim of finding an ideal regimen with higher efficacy and lower side effects: (i) treatment for 30 consecutive days, which has already been shown to be effective for suppressing parasitaemia with fewer side effects (Coura et al. 1978, Coura et al. 1997), (ii) over an interval of 30-60 days, clinical and laboratory evaluations should be conducted (haemogram, serological tests, xenodiagnosis and real-time polymerase chain reactions) to assess possible abnormalities and to reduce or eliminate the presence of the parasite in the organism, (iii) repetition of a regimen every 60 days, over a six-month to oneyear period according to the clinical, parasitological and serological responses and the possible side effects from the regimen and (iv) evaluation of cure in accordance with the criteria established by Rassi \& Luquetti (2005), including clinical, electrocardiographic, radiological, parasitological and serological evaluations.

\section{REFERENCES}

Andrade AL, Zicker F, Oliveira RM, Silva AS, Luquetti AO, Travassos LR, Almeida IC, Andrade SS, Andrade JG 1996. Randomised trial efficacy of benznidazole in the treatment of early Trypanosoma cruzi infection. Lancet 318: 1407-1413.

Andrade SG, Stocker-Guerret S, Pimentel AS, Grimaud JA 1991. Reversibility of cardiac fibrosis in mice chronically infected with Trypanosoma cruzi under specific chemotherapy. Mem Inst Oswaldo Cruz 86: 187-200.

Anonymous 1985. Reunião de Pesquisa Aplicada em doença de Chagas. Validade do conceito de forma indeterminada. Rev Soc Bras Med Trop 18: 46.

Borges-Pereira J 1997. Doença de Chagas humana: estudo da infecção crônica, morbidade e mortalidade em Virgem da Lapa, $M G$, Brasil, PhD Thesis, Instituto Oswaldo Cruz/Fiocruz, Rio de Janeiro, 177 pp.

Borges-Pereira J, Willcox HP, Coura JR 1985. Morbidade da doença de Chagas. III - Estudo longitudinal de seis anos em Virgem da Lapa, MG, Brasil. Mem Inst Oswaldo Cruz 80: 63-71.

Brener Z 1961. Atividade terapêutica do 5-nitrofuraldeido-semicarbazona (nitrofurazona) em esquemas de duração prolongada na infecção experimental pelo Trypanosoma cruzi. Rev Inst Med Trop Sao Paulo 3: 43-49.

Cançado JR 1968. Tratamento da doença de Chagas. In JR Cançado, Doença de Chagas, Imprensa Oficial de Minas Gerais, Belo Horizonte, p. 517-540.

Carrasco HA, Palacios PE, Scorza C, Molina C, Iglessis G, Mendoza RV 1987. Clinical, histochemical and ultrastructural correlation in septal endomyocardial biopsies from chronic chagasic patients: detection of early myocardial damage. Am Heart J 113: 716-724.

Castro CN 1978. Influência da parasitemia no quadro clínico da doença de Chagas, Master Degree Thesis, Universidade de Brasília, Brasília, 95 pp.

Chagas C 1916. Processos patojenicos da tripanozomiase americana. Mem Inst Oswaldo Cruz 8: 5-35.

Chagas C, Chagas E 1935. Manual de doenças tropicais e infectuosas, vol. I, Livraria Editora Freitas Bastos, Rio de Janeiro, 189 pp.

Coura JR 1975. Evolutive pattern of Chagas disease and the life span of Trypanosoma cruzi. International Symposium on New Approches in American Trypanosomiasis Research. PAHO Sci Publ 318: 378-383.

Coura JR 1996. Perspectivas actuales del tratamiento específico de La enfermedad de Chagas. Bol Chil Parasitol 51: 69-75.

Coura JR 2007. Chagas disease: what is known and what is needed - A background article. Mem Inst Oswaldo Cruz 102 (Suppl. I): 113-122.

Coura JR 2009. Present situation and new strategies for Chagas disease chemotherapy - a proposal. Mem Inst Oswaldo Cruz 104: 549-554.

Coura JR, Abreu LL, Borges-Pereira J, Willcox HP 1985. Morbidade da doença de Chagas. IV. Estudo longitudinal de dez anos em Pains e Iguatama, Minas Gerais, Brasil. Mem Inst Oswaldo Cruz 80: 73-80. 
Coura JR, Abreu LL, Dubois LEG, Correia-Lima F, Arruda-Junior E, Willcox HPF, Petana W 1984. Morbidade da doença de Chagas. II. Estudos seccionais em quatro áreas de campo no Brasil. Mem Inst Oswaldo Cruz 79: 101-124.

Coura JR, Abreu LL, Willcox HPF, Petana W 1997. Comparative controlled study on the use of benznidazole, nifurtimox and placebo in the chronic form of Chagas disease in a field area with interrupted transmission. I - Preliminar evaluation. Rev Soc Bras Med Trop 30: 139-144.

Coura JR, Anunziato N, Willcox HPF 1983. Morbidade da doença de Chagas. I. Estudo de casos de vários estados do Brasil observados no Rio de Janeiro. Mem Inst Oswaldo Cruz 78: 363-372.

Coura JR, Borges-Pereira J 2010. Chagas disease: 100 years after its discovery. A systemic review. Acta Tropica 115: 5-13.

Coura JR, Brindeiro PJ, Ferreira I 1978. Benznidazole in the treatment of Chagas disease. Current chemotherapy. Proc 10th Int Cong Chemotherapy 1: 161-162.

Coura JR, De Castro SL 2002. A critical review on Chagas disease chemotherapy. Mem Inst Oswaldo Cruz 97: 3-24.

Coura JR, Ferreira LF, Saad EA, Mortel RE, Silva JR 1961. Tentativa terapêutica com nitrofurazona (Furacin) na forma crônica da doença de Chagas. O Hospital 60: 425-429.

Coura JR, Ferreira LF, Silva JR 1962. Experiências com nitrofurazona na fase crônica da doença de Chagas. O Hospital 62: 957-964.

Coura JR, Junqueira ACV, Boia MN, Fernandes O 1999. Chagas disease: from bush to huts and houses. Is it the case of the Brazilian Amazon? Mem Inst Oswaldo Cruz 94 (Suppl. I): 379-384.

Coura JR, Silva JR 1961. Aspectos atuais do tratamento da doença de Chagas. Arq Bras Med 51: 283-290.

Dias JCP 1982. Doença de Chagas em Bambui, Minas Gerais, Brasil. Estudo clínico-epidemiológico a partir da fase aguda, entre 1940 a 1982, PhD Thesis, Universidade Federal de Minas Gerais, Belo Horizonte, 376 pp.

Dias JCP 1989. The indeterminate form of human chronic Chagas disease. A clinical and epidemiological review. Rev Soc Bras Med Trop 22: 147-156.

Diaz de Taranzo EG, Castro JA, Frank de Cazzulo JJ 1988. Interaction of benznidazole reactive metabolites with nuclear and kinotoplastic DNA, protein and lipids from Trypanosoma cruzi. Experientia 44: 880-881.

Do Campo R, Moreno SNJ 1986. Free radical metabolism of antiparasitic agent. Fed Proceed 45: 2471-2476.

Ferreira HO 1961. Forma aguda da doença de Chagas tratada pela nitrofurazona. Rev Inst Med Trop Sao Paulo 3: 287-289.

Ferreira HO 1962. Fase aguda da doença de Chagas. O Hospital 61: 307-311.

Ferreira HO, Prata A, Rassi A 1963. Administração prolongada de nitrofurazona no tratamento da doença de Chagas aguda. $\mathrm{O} \mathrm{Hos}$ pital 63: 1391-1396.

Laranja FS, Dias E, Nóbrega MD, Miranda A 1956. Chagas disease. A clinical, epidemiologic and pathological study. Circulation 14: 1035-1060.

Luquetti AO 1997. Etiological treatment for Chagas disease. Parasitol Today 13: 127-128.

Macedo VO 1980. Forma indeterminada da doença de Chagas. J Bras Med 38: 34-40.

Macedo VO, Prata A, Silva GR, Castilho E 1982. Prevalência de alterações eletrocardiográficas em chagásicos (informações preliminares sobre o inquérito eletrocardiográfico nacional). Arq Bras Cardiol 38: 261-264.
Mady C, Barretto AC, Ianni BM, Lopes EA, Pileggi F 1984. Right ventricular endomyocardial biopsy in indeterminate form of Chagas disease. Angiology 35: 755-759.

Mayer M, Rocha Lima H 1912. Zur Entwicklung von Schizotrypanum cruzi in Saengetieren. Arch f Schisffs u Tropen Hyg 16: 90-94.

Mayer M, Rocha Lima H 1914. Zum verhalten von Schizotrypanum cruzi in Warmblutern un Arthopoden. Arch Schiffs u Tropen Hyg 18: 101-136.

NYHA - New York Heart Association 1973. Nomenclature and criteria for diagnosis of disease of the heart and great vessels, 7th ed., Little and Brown Company, Boston, 347 pp.

Packchanian A 1952. Chemotherapy of experimental Chagas disease with nitrofuran compounds. J Parasitol 38: 30-40.

Packchanian A 1957. Chemotherapy of experimental Chagas disease with nitrofuran compounds. Antibiot Chemother 7: 13-23.

Polak A, Richle R 1978. Mode of action of 2-nitroimidazole derivative benznidazole. Ann Trop Med Parasitol 72: 228-232.

Prata A 2001. Clinical and epiemiological aspects of Chagas disease. The Lancet Infect Dis 1: 92-100.

Prata A, Lopes EA, Chapadeiro E 1986. Características da morte súbita não esperada na doença de Chagas. Rev Soc Bras Med Trop 19: 9-12.

Rassi A, Luquetti AO 2005. Critérios de cura da infecção pelo Trypanosoma cruzi na espécie humana. In JR Coura (ed.), Dinâmica das doenças infecciosas e parasitárias, Editora Guanabara Koogan, Rio de Janeiro, p. 677-683.

Rassi-Junior, Rassi A, Rassi SG 2005. Prediction of mortality in chronic Chagas disease. A systemic review of observational studies. Circulation 115: 1101-1108.

Rezende JM, Lauar KL, Oliveira AR 1960. Aspectos clínicos e radiológicos da aperistalsis do esôfago. Rev Bras Gastroenterol 12: $247-262$.

Rezende-Filho J, Moreira-Junior H, Rezende JM 2005. Métodos radiológicos e manométricos para o diagnóstico da esofagopatia e da colopatia chagásica. In JR Coura (ed.), Dinâmica das doenças infecciosas e parasitárias, Editora Guanabara Koogan, Rio de Janeiro, p. 653-666.

Ribeiro ALP, Rocha MOC 1998. Forma indeterminada da doença de Chagas. Considerações acerca do diagnóstico e prognóstico. Rev Soc Bras Med Trop 31: 301-314.

Ribeiro ALP, Rocha MOC 2000. Forma indeterminada da doença de Chagas. In Z Brener, ZA Andrade, M Bararl-Neto, Trypanosoma cruzi e Doença de Chagas, 2nd ed., Editora Guanabara Koogan, Rio de Janeiro, p. 245-265.

Rocha MOC, Barros MVL, Tostes VTV, Junqueira LJ, Ribeiro ALP 2005. Métodos de avaliação funcional não-invasivos da cardiopatia chagásica e outras cardiopatias infecciosas. In JR Coura, Dinâmica das doenças infecciosas e parasitárias, Editora Guanabara Koogan, Rio de Janeiro, p. 639-652.

Sosa-Estani S, Segura EL, Ruiz AM, Porcel BM, Yampotis C 1998. Efficacy of chemotherapy with benznidazole in children in the intermediate phase of Chagas disease. Am J Trop Med Hyg 59: 526-529.

SVS/MS - Secretaria de Vigilância em Saúde/Ministério da Saúde 2005. Consenso Brasileiro em Doença de Chagas. Rev Soc Bras Med Trop 38 (Suppl. III): 11-14.

Vianna G 1911. Contribuição para o estudo da anatomia patológica da "Moléstia de Carlos Chagas". Mem Inst Oswaldo Cruz 3: 276-293.

Villela E 1923. Moléstia de Chagas (2 parte). Folha Med 4: 41-43. 